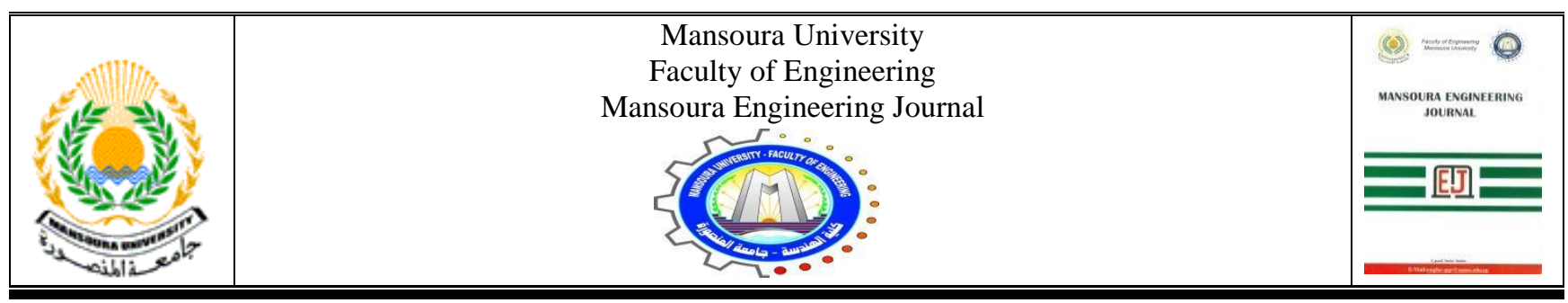

\title{
Effect of Supporting Soil on the Seismic Response of Elevated Water Tanks under Different Excitations
}

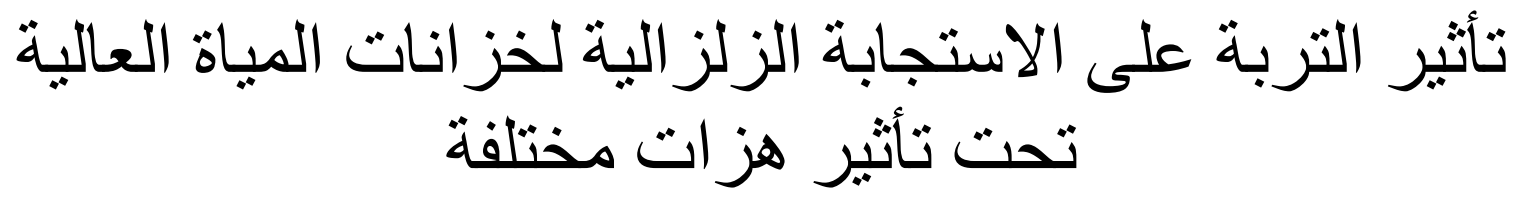

Ahmed M. El Khawaga, Ahmed E. El Nimr and Adel M. Gabr

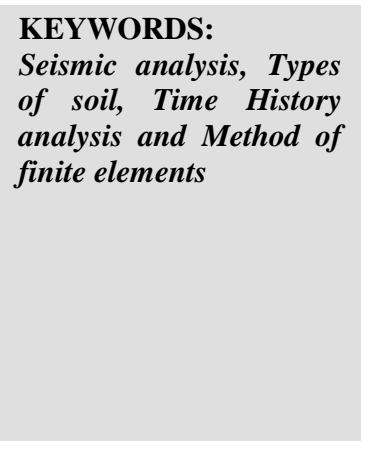

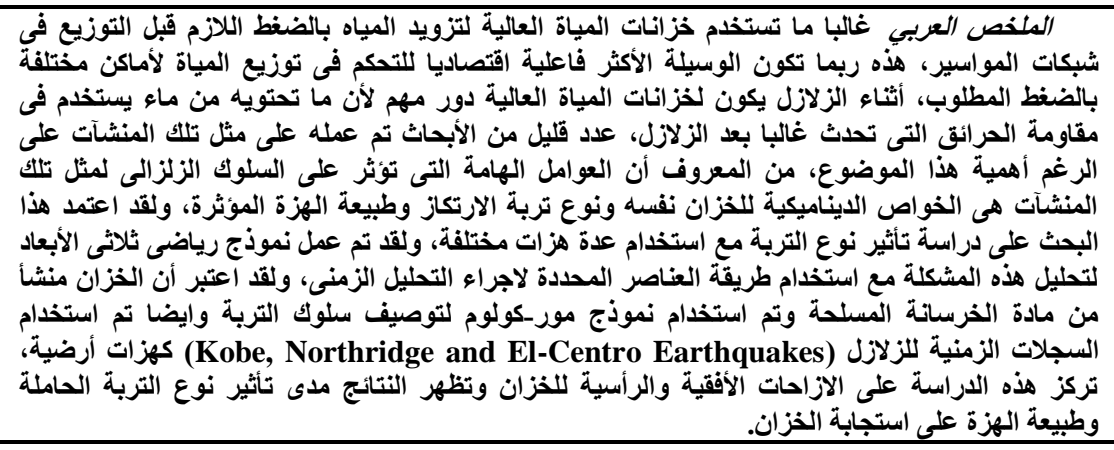

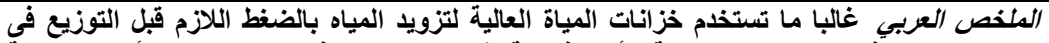

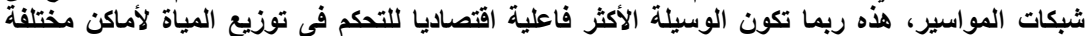

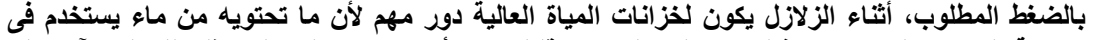

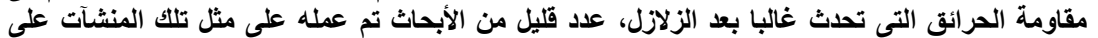

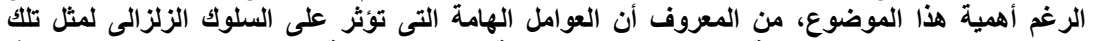

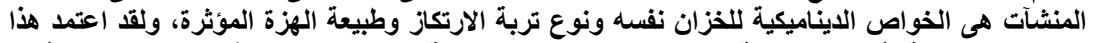

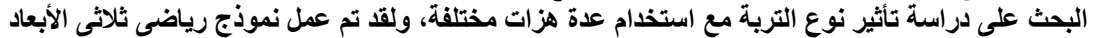

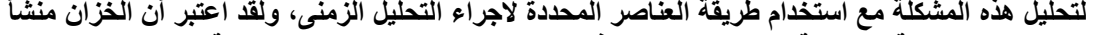
من مادة الخرسانة المسلحة وتم استخدام نموذج مور-كولوم لتوصيف سلوك التربة الترة وايضا تم استخدام

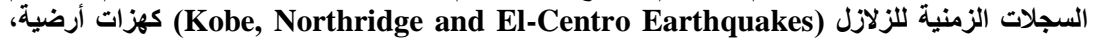
وطبيعة الهزة على استجابة الخزه على الزان.

\begin{abstract}
Elevated water tanks are generally used to provide a high fluid pressure before distribution through pipe network. This may be the most economic mean to control the water distribution to different locations with the needed pressure. During earthquakes, the elevated water tanks have a very important role because the contained water can be used to resist fires which generally occur after earthquakes. Small numbers of researches have been done on the seismic behavior of this type of structures compared to the importance of the problem. The important factors that influence the seismic behavior of such structures are the dynamic properties of the tank itself, the structure-soil system and the excitation time history. Soil type
\end{abstract}

Received: 23 February, 2016 - accepted: 7 May, 2016.

Ahmed M. El Khawaga, MSc. Student, Structural Engineering Dept., Faculty of Engineering, Mansoura University.

Ahmed E. El Nimr, Professor, Structural Engineering Dept., Faculty of Engineering, Mansoura University

Adel M. Gabr, Assoc. Professor, Structural Engineering Dept., Faculty of Engineering, Mansoura University and different excitations time histories are the governing factors in this study. A three dimensional model is constructed to analyze the problem. Time History analysis has been performed using the method of finite elements. In the analysis, the tank material is assumed to be reinforced concrete. The MohrCoulomb model has been used to describe the behavior of the soil model. Kobe, Northridge and El-Centro Earthquake records are used in this study as the bedrock Excitation. The study focuses on the horizontal and vertical displacements of the tank. The results show the effect of different types of supporting soil and different excitations on the seismic response of the tank.

\section{INTRODUCTION}

$\mathrm{U}$ sing water tanks is an ancient facility to store water. Most of the ancient tanks were ground tanks. But now and according to the vertical development of the cities, the elevated water tanks were the most economic mean to provide water with the required 
pressure to reach the upper floors. So, numerous of elevated water tanks were built everywhere for that reason. Also, water stored in the elevated water tanks is used to resist fires. As fires generally follow earthquakes, the elevated water tanks must be functional during and after earthquakes. For that reason structural designers focus on studying the seismic behavior of such structures. Elevated water tanks consist of huge water masses at the top of slender stagings which need critical considerations against the failure of the tank during earthquakes. Poor performance of some elevated water tanks in past earthquakes may be an indication of lack of knowledge regarding the seismic behavior of the elevated water tanks.

\section{Past Failures Cases}

In the Bhuj 2001 earthquake in India, three elevated water tanks collapsed completely, and many more were damaged severely. A collapsed elevated water tank in Bhuj 2001 earthquake is shown in Fig.1. The tank was about half full during the earthquake. Fig. 2 shows also a collapsed framesupported elevated water tank in the Killari 1993 Earthquake. Similar damages were also reported in the Jabalpur 1997, Kashmir 2005 and Chilean 1960 earthquakes [12, 15, 16, 19]

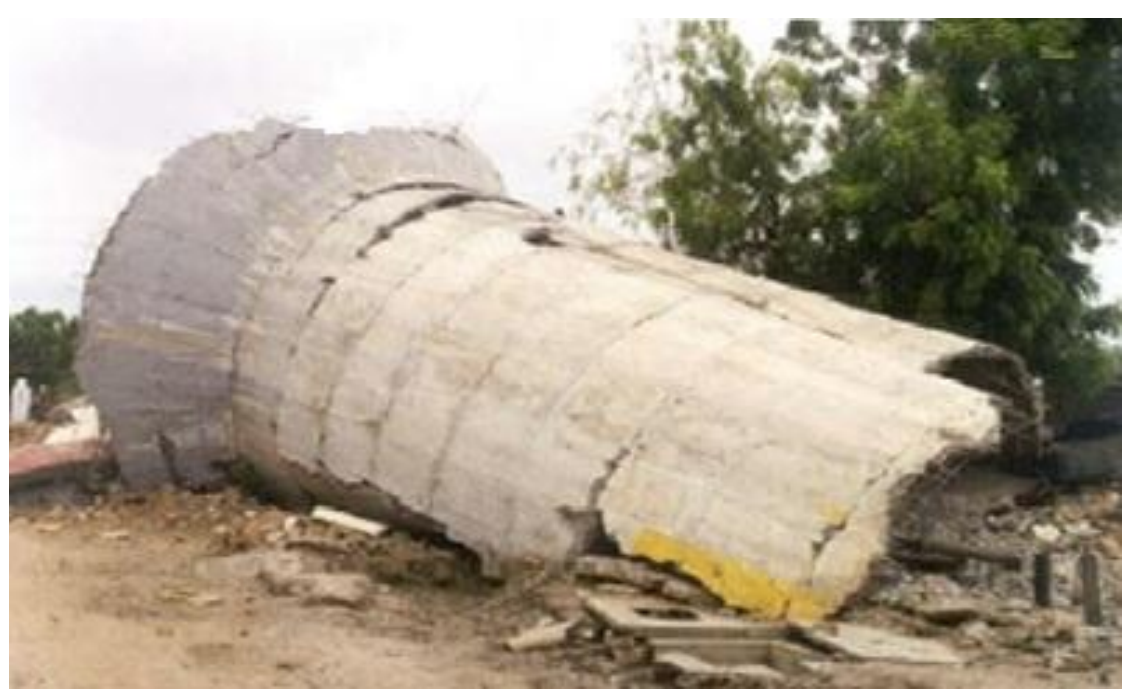

Fig.1 Collapsed elevated water tank in Bhuj 2001 earthquake

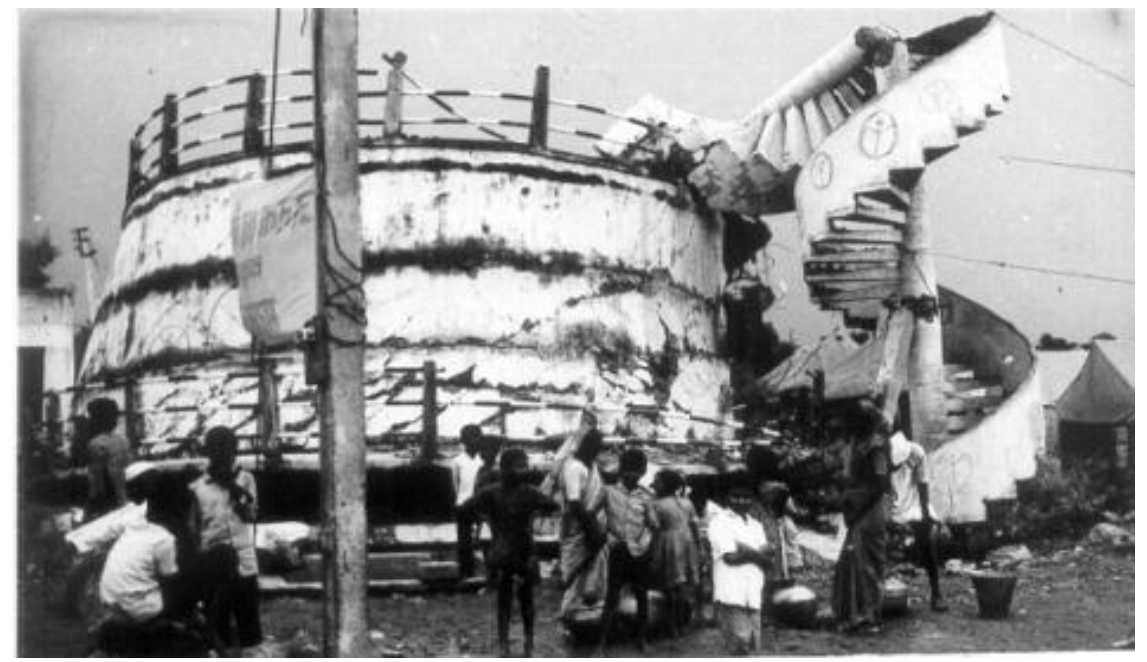

Fig.2 Collapsed elevated water tank in Killari 1993 earthquake

\section{LITERATURE REVIEW}

The first model assumed to describe the seismic behavior of the elevated water tank was the single lumped mass model suggested by (Chandrasekaran and Krishna, 1954) [14]. This concept has some disadvantages: i) neglecting the sloshing effect of the contained water on the seismic behavior of the tank[3], ii) neglecting the non-uniform rigidity of the supporting structure along its height and iii) neglecting the effect of the supporting soil on the seismic behavior. Fig.3 shows the elevated water tanks and the single lumped mass model. $\mathrm{M}$ : the lumped mass and $\mathrm{K}$ : uniform rigidity of the supporting frame.

To consider the seismic behavior of elevated tanks, a mechanical model with two masses idealization was suggested by (Housner, 1963) [13, 10]. This concept assumed that the vessel is rigid. The pressure which occurs by the fluid when the tank exposed to a dynamic load can be represented 
according to this idealization by two separate masses impulsive and convective. This idealization assumed that these masses are produced when an elevated water tank containing fluid with free surface excited by a dynamic load. The liquid in the lower zone of the tank vessel behaves like a mass rigidly connected to the vessel wall and base. This mass is called the impulsive mass. By the same way the other part of the liquid which lay on the upper zone of the tank vessel undergoes sloshing motions. This part of mass is called the convective liquid mass. The supporting structure mass is also divided into two parts; the first part to be considered the mass of the container, roof slabs and two-third of the staging mass and added to the impulsive mass. The remaining part of the staging mass is considered to act directly on the tank
foundation.This equivalent mechanical model is shown in Fig.4 (A).

In case of elevated tanks with flexible vessels (generally steel vessels), the previous mechanical model was modified by (Haroun and Housner, 1981) [8, 18]. This development assumed that when the tank is exposed to base excitation, the contained fluid undergoes like three parts: i) the upper part with the free surface and mass mc (convective mass), ii) the liquid in the lower part of the vessel with mass mr (rigid mass) and iii) the liquid in the intermediate part of the vessel which oscillates with the vessel wall with mass mi (impulsive mass). This mechanical model is illustrated in Fig.4 (B).

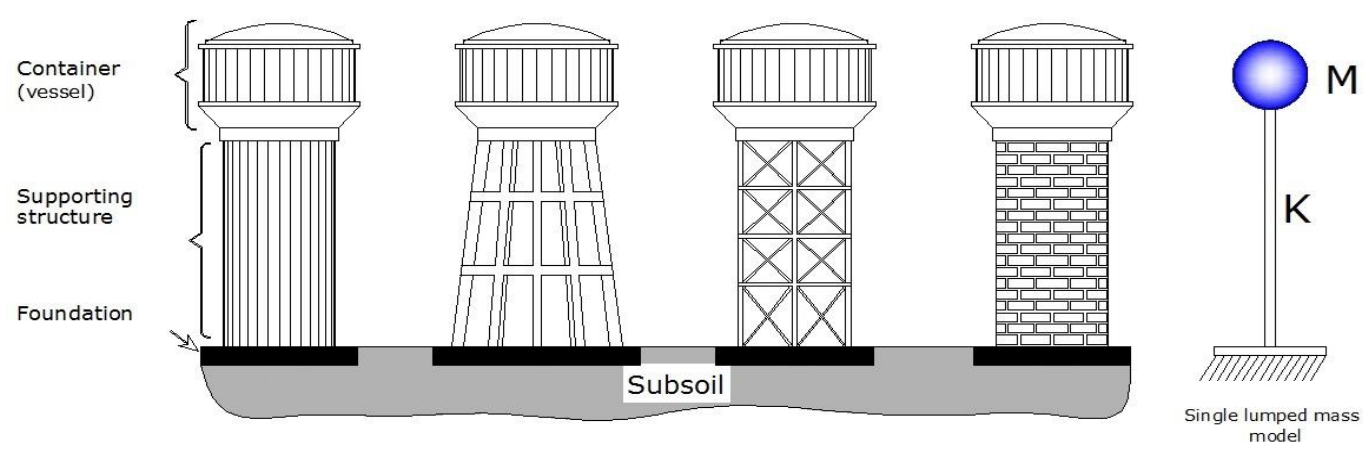

Fig.3 Elevated water tanks and the lumped mass model

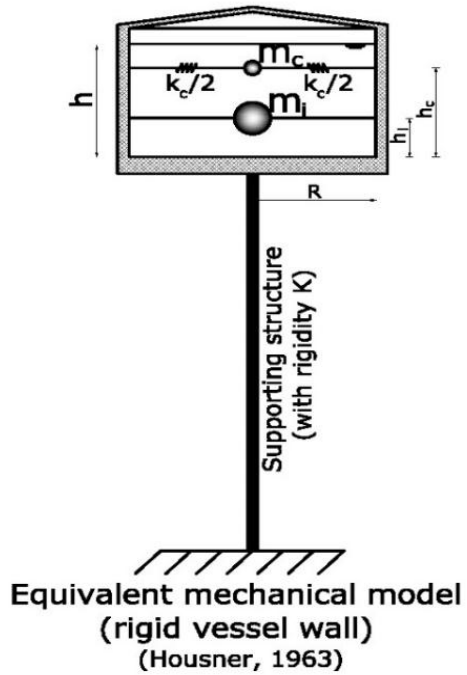

(A)

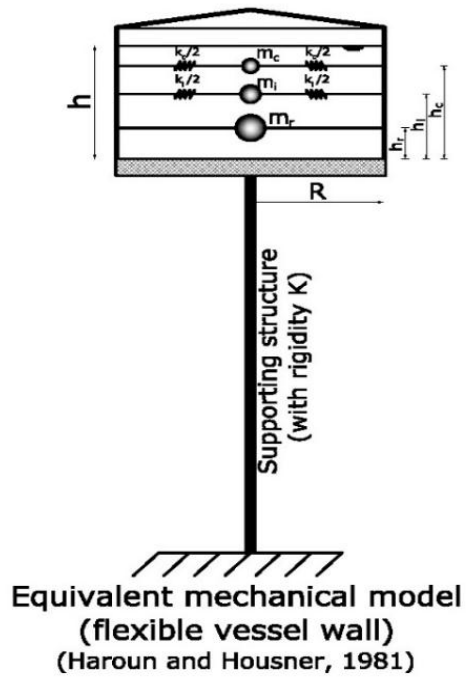

(B)

Fig.4 Mechanical models of the elevated water tanks

Many researches modified the previous mechanical models to consider the soil-structure interaction. Considering the soilstructure interaction is very important because the supporting soil isn't rigid enough material to be treated as a fixed support. (Livaoglu and Dongangun, 2006; Dutta, et al., 2004, 2009)[5, 6] used flexible support for the tank to overcome this problem.

Recently and after spread of computers and Finite Element softwares, many programs can execute both static and dynamic analysis for such structures like ADINA and ANSYS
$[1,2]$. These programs have large data, variety of material models and element groups. Many researches used these programs in the seismic analysis of elevated tanks $[7,8,15$, 17]. This technique will be used in this research.

\section{MODEL DESCRIPTIONS}

The elevated tank physical model which is considered in 
this study is assumed to be a reinforced concrete elevated tank with shaft staging and has the geometry and concrete dimensions as shown in Fig.5.The figure also shows the naming methodology for the models to easily distinguish between them. The 6 characters ID for each model is a useful way to identify the parameters considered. The first 2 characters refer to the tank case (full or empty), the second 2 characters refers to the excitation used (KO for Kobe earthquake, NO for Northridge earthquake and EL for El Centro earthquake) and the last 2 characters refer to the soil type (S1 for stiff clay, S2 for very stiff clay, S3 for dense sand and S4 for very dense sand). The study models were built using 2D solid elements for the shaft, vessel wall and the vessel roof. The raft of the tank and the vessel's base were modeled as 3D solid elements. Mohr-coulomb model was used to describe the nonlinear behavior of the soil domain. The water contained by the tank was modeled using a potentialbased fluid material. The reinforced concrete material was assumed to have a modulus of elasticity $\mathrm{E}$ of $20.0 \mathrm{GPa}$, density of $2500 \mathrm{~kg} / \mathrm{m} 3$ and Poisson's ratio $(v)=0.25$. The water has bulk modulus of $2.0 \mathrm{GPa}$ and density of $1000 \mathrm{~kg} / \mathrm{m} 3$. The mechanical properties of the different soil types which are considered in this study are shown in Table 1 [4]. 3D Finite Element model of the elevated water tank developed by the ADINA program is illustrated in Fig.6

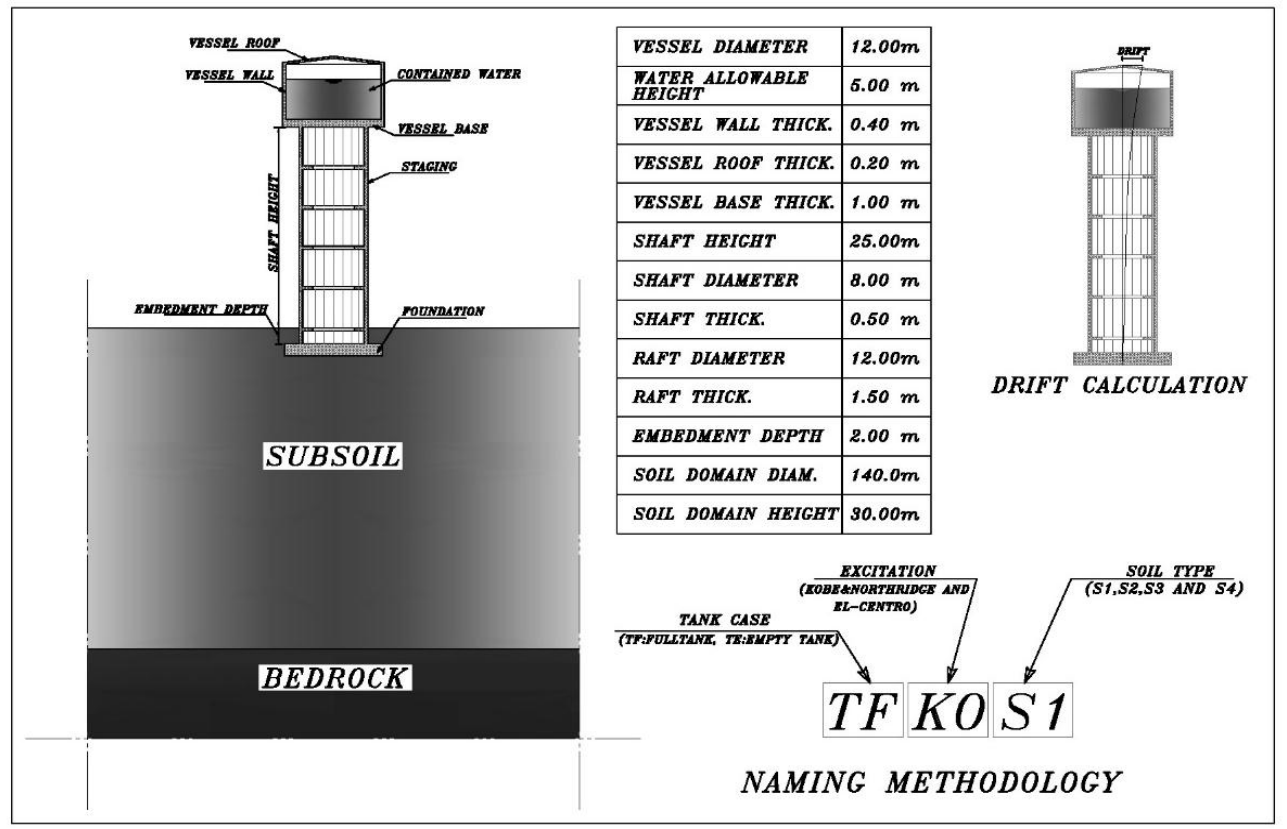

Fig.5 Geometry, concrete dimensions, drift calculation, naming methodology for the models used in the research

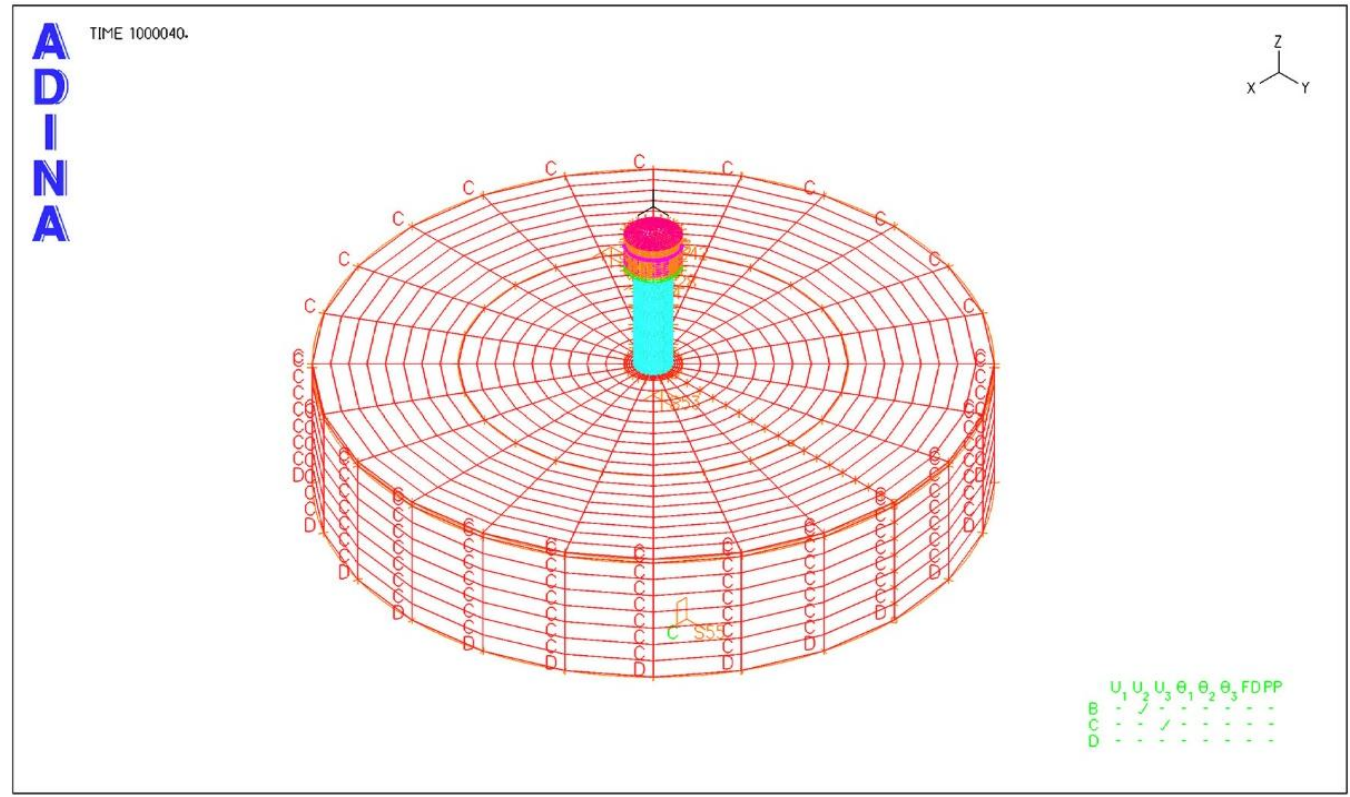

Fig.6 3D Finite Element model developed by ADINA program 
C: 10 MANSOURA ENGINEERING JOURNAL, (MEJ), VOL. 41, ISSUE 2, JUNE 2016

\begin{tabular}{c|l|c|c|c|c|c|c}
\multicolumn{7}{|c|}{ TABLE 1. MECHANICAL PROPERTIES OF SOIL TYPES CONSIDERED } \\
$\begin{array}{c}\text { Soil } \\
\text { type }\end{array}$ & Description & $\begin{array}{c}\text { Density } \\
\left(\mathrm{kg} / \mathrm{m}^{3}\right)\end{array}$ & $\begin{array}{c}\text { Cohesion } \\
(\mathrm{KPa})\end{array}$ & $\begin{array}{c}\text { Compressive } \\
\text { modulus }(\mathrm{MPa})\end{array}$ & $\begin{array}{c}\text { Angle of } \\
\text { internal } \\
\text { friction }(\phi)\end{array}$ & $\begin{array}{c}\text { Angle of } \\
\text { dilation }(\psi)\end{array}$ & $\begin{array}{c}\text { Poisson } \\
\text { ratio( }(v)\end{array}$ \\
\hline S1 & Stiff clay & 1800 & 80 & 10 & 1 & 0.00001 & 0.4 \\
\hline S2 & Very stiff clay & 1860 & 150 & 20 & 1 & 0.00001 & 0.4 \\
\hline S3 & Dense sand & 1800 & 1 & 80 & 36 & 6 & 0.4 \\
\hline S4 & Very dense sand & 1900 & 1 & 150 & 41 & 11 & 0.4
\end{tabular}

\begin{tabular}{l|l|l|l}
\multicolumn{5}{|c}{ TABLE 2. CONSIDERED EARTHQUAKES DATA } \\
Earthquake & Date & Magnitude & PGA \\
\hline Kobe & January 1995 & 6.9 & $0.821 \mathrm{~g}$ \\
\hline Northridge & January 1994 & 6.7 & $0.217 \mathrm{~g}$ \\
\hline El-Centro & May 1940 & 7.1 & $0.350 \mathrm{~g}$
\end{tabular}

Three earthquake time histories which are considered in this study; Kobe, Northridge and El-Centro earthquakes. Table 2 shows these earthquakes data. The acceleration time histories and corresponding displacement time histories for them are shown in Fig.7. All the records are scaled to have a
PGA of $0.2 \mathrm{~g}$ in this study. The 40 second records consists of 20 seconds excitation followed by 20 seconds without movement

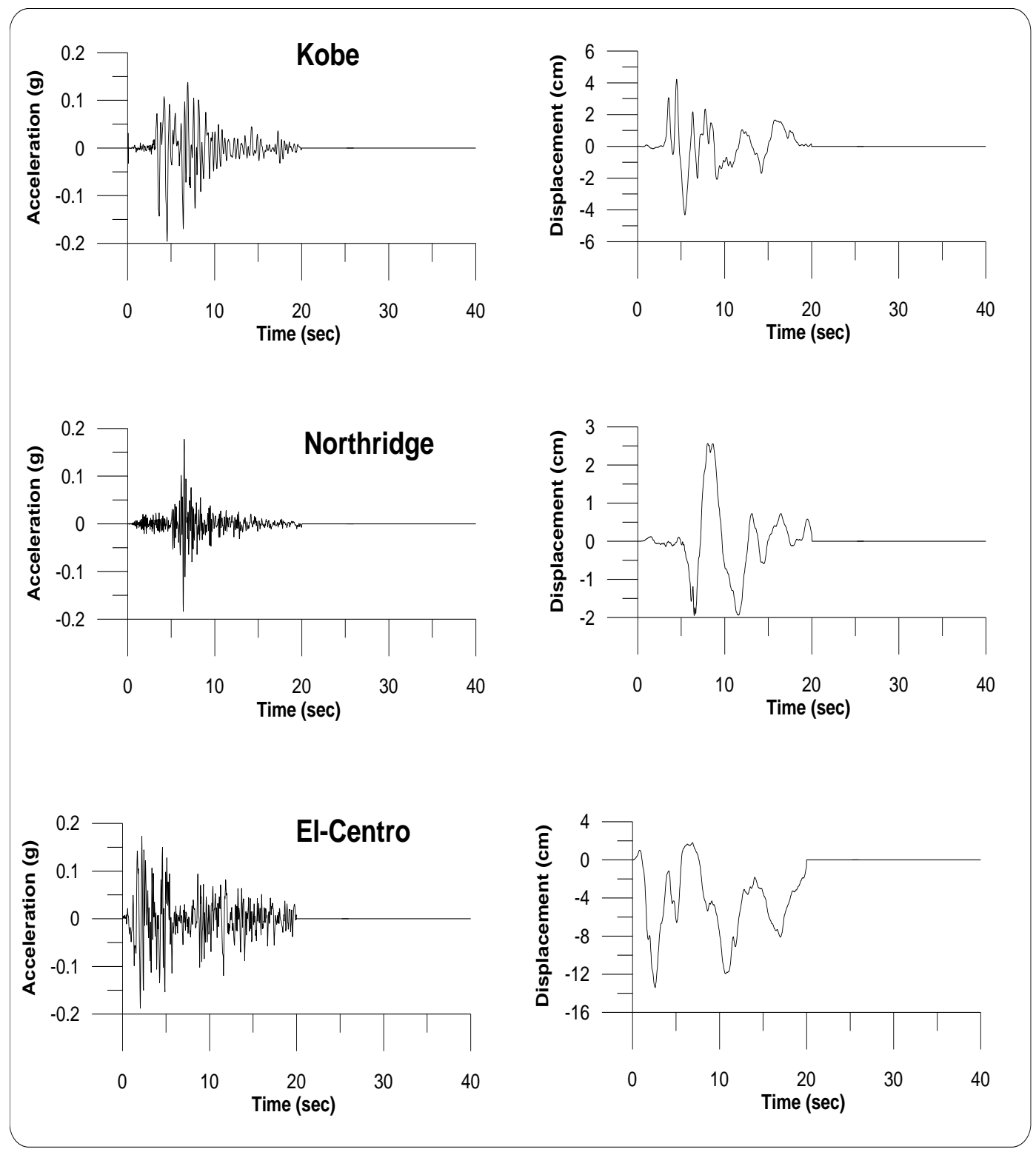

Fig.7 Acceleration time histories and displacement time histories for Kobe, Northridge and El-Centro Earthquakes 


\section{RESUlts OF THE STUDY}

The results obtained from the study will be represented in this section. The effect of the supporting soil on the seismic response will be shown considering each excitation separately for both full and empty models. Fig. 8 shows the drift time history and the vertical displacement for empty tank models with Kobe earthquake as seismic excitation considering different types of soil (TEKOS1, TEKOS2, TEKOS3 and TEKOS4). The maximum drift for TEKOS1 is $43.70 \mathrm{~cm}$ at time $14.86 \mathrm{sec}, 52.35 \mathrm{~cm}$ at time $9.58 \mathrm{sec}$ for TEKOS2, 18.99 $\mathrm{cm}$ at time $9.74 \mathrm{sec}$ for TEKOS3 and $9.69 \mathrm{~cm}$ at time 8.68 for TEKOS4.

The drift time history and the vertical displacement related to the full tank models (TFKOS1, TFKOS2, TFKOS3 and TFKOS4) are shown in Fig.9. The maximum drift for
TFKOS1 is $39.63 \mathrm{~cm}$ at time $14.20 \mathrm{sec}, 48.47 \mathrm{~cm}$ at time 9.08 $\mathrm{sec}$ for TFKOS2, $14.96 \mathrm{~cm}$ at time $8.00 \mathrm{sec}$ for TFKOS3 and $9.24 \mathrm{~cm}$ at time 5.42 for TFKOS4

The previous results shown in Fig.8 and Fig.9 are related to tank models analyzed considering Kobe earthquake as bedrock excitation for both cases; full and empty. While results shown below in Fig.10 and Fig.11 are related to those models analyzed considering Northridge earthquake.

The drift time history and the vertical displacement for TENOS1, TENOS2, TENOS3 and TENOS4 can be seen in Fig.10. The maximum drift for TENOS1 is $9.10 \mathrm{~cm}$ at time $18.76 \mathrm{sec}, 4.40 \mathrm{~cm}$ at time $10.94 \mathrm{sec}$ for TENOS2, $3.02 \mathrm{~cm}$ at time $11.42 \mathrm{sec}$ for TENOS3 and $3.52 \mathrm{~cm}$ at time 7.54 for TENOS4.

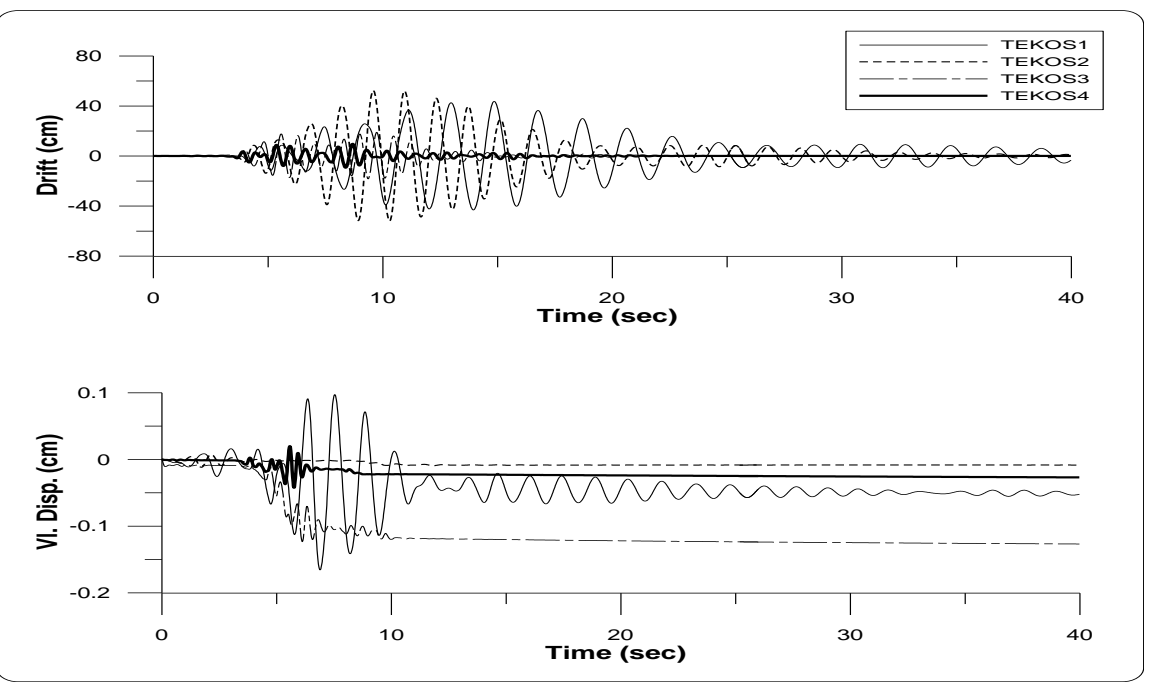

Fig. 8 Drift time history and the vertical displacement for TEKOS1, TEKOS2, TEKOS3 and TEKOS4
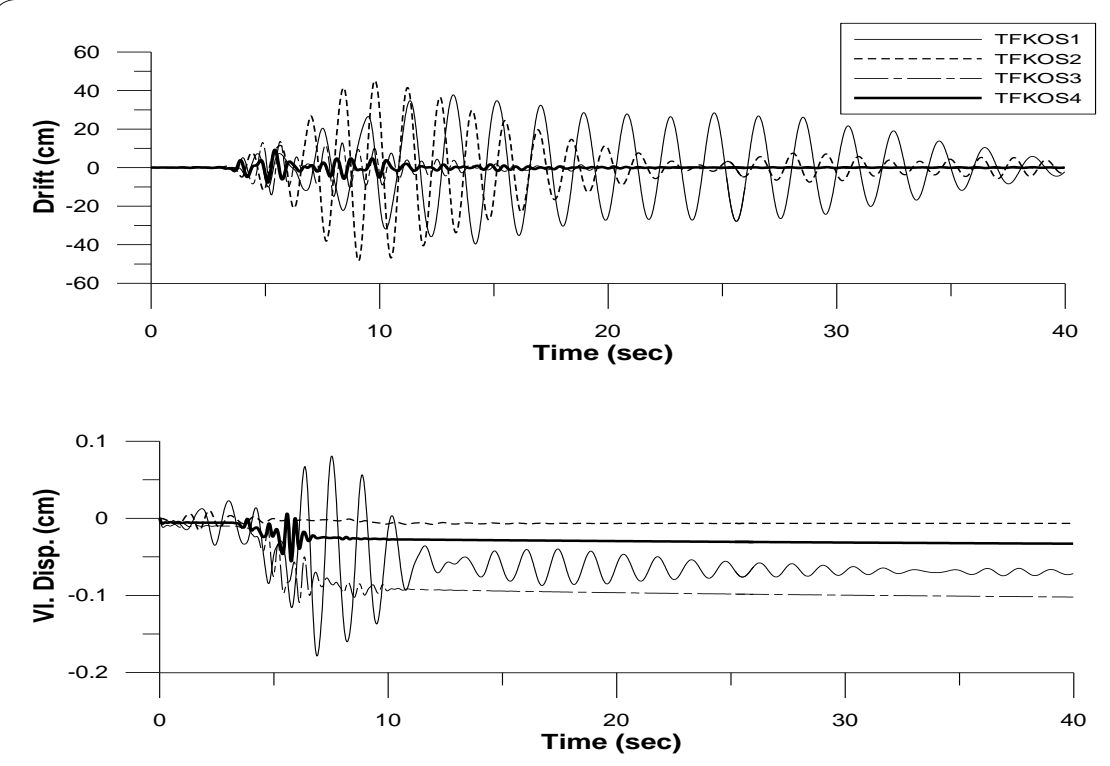

Fig.9 Drift time history and the vertical displacement for TFKOS1, TFKOS2, TFKOS3 and TFKOS4 
The drift time history and the vertical displacement for TFNOS1, TFNOS2, TFNOS3 and TFNOS4 are illustrated in Fig.11. The maximum drift for TFNOS1 is $9.15 \mathrm{~cm}$ at time $18.96 \mathrm{sec}, 4.96 \mathrm{~cm}$ at time $11.12 \mathrm{sec}$ for TFNOS2, $1.93 \mathrm{~cm}$ at time $14.22 \mathrm{sec}$ for TFNOS3 and $2.54 \mathrm{~cm}$ at time 7.56 for TFNOS4.

The previous results shown in Fig.8 and Fig.9 are related to tank models analyzed considering Kobe earthquake as bedrock excitation for both cases; full and empty. While results shown below in Fig.10 and Fig.11 are related to those models analyzed considering Northridge earthquake.

The drift time history and the vertical displacement for TENOS1, TENOS2, TENOS3 and TENOS4 can be seen in Fig.10. The maximum drift for TENOS1 is $9.10 \mathrm{~cm}$ at time $18.76 \mathrm{sec}, 4.40 \mathrm{~cm}$ at time $10.94 \mathrm{sec}$ for TENOS2, $3.02 \mathrm{~cm}$ at time $11.42 \mathrm{sec}$ for TENOS3 and $3.52 \mathrm{~cm}$ at time 7.54 for
TENOS4.

The drift time history and the vertical displacement for TFNOS1, TFNOS2, TFNOS3 and TFNOS4 are illustrated in Fig.11. The maximum drift for TFNOS1 is $9.15 \mathrm{~cm}$ at time $18.96 \mathrm{sec}, 4.96 \mathrm{~cm}$ at time $11.12 \mathrm{sec}$ for TFNOS2, $1.93 \mathrm{~cm}$ at time $14.22 \mathrm{sec}$ for TFNOS3 and $2.54 \mathrm{~cm}$ at time 7.56 for TFNOS4

The results shown below in Fig.12 and Fig.13 are related to those models analyzed considering El-Centro earthquake.

Fig.12 shows the drift time history and the vertical displacement for TEELS1, TEELS2, TEELS3 and TEELS4. The maximum drift for TEELS1 is $45.38 \mathrm{~cm}$ at time $12.48 \mathrm{sec}$, $27.56 \mathrm{~cm}$ at time $16.20 \mathrm{sec}$ for TEELS2, $13.32 \mathrm{~cm}$ at time 6.68 $\mathrm{sec}$ for TEELS3 and $12.35 \mathrm{~cm}$ at time 2.34 for TEELS4.

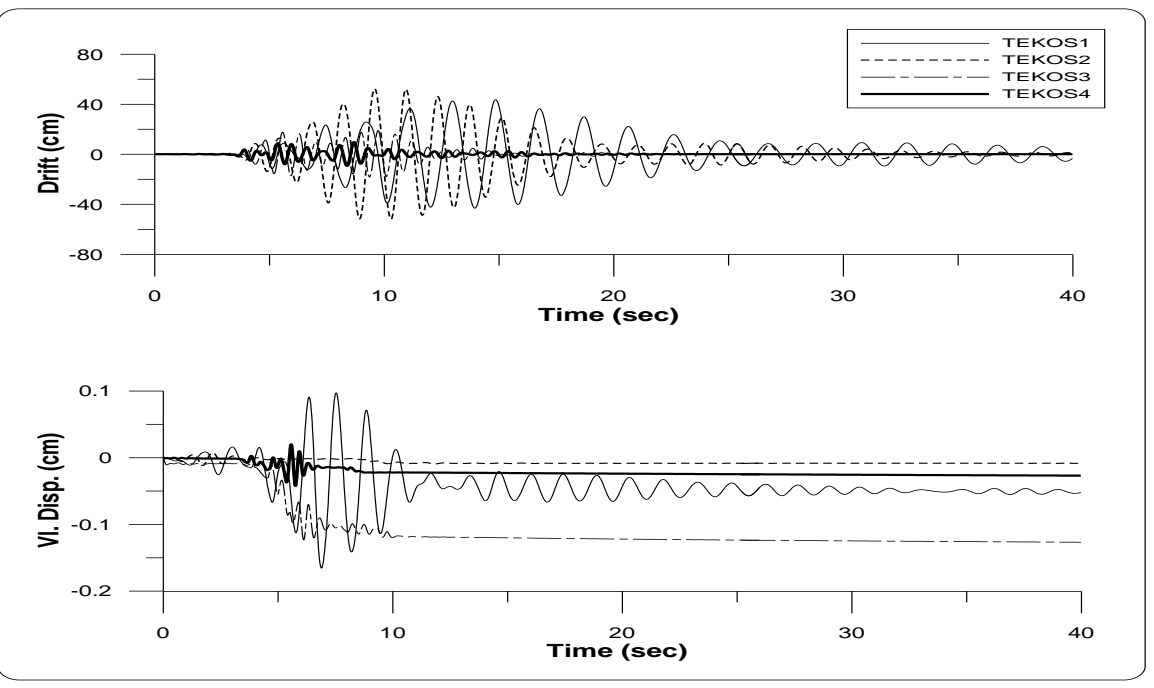

Fig.8 Drift time history and the vertical displacement for TEKOS1, TEKOS2, TEKOS3 and TEKOS4
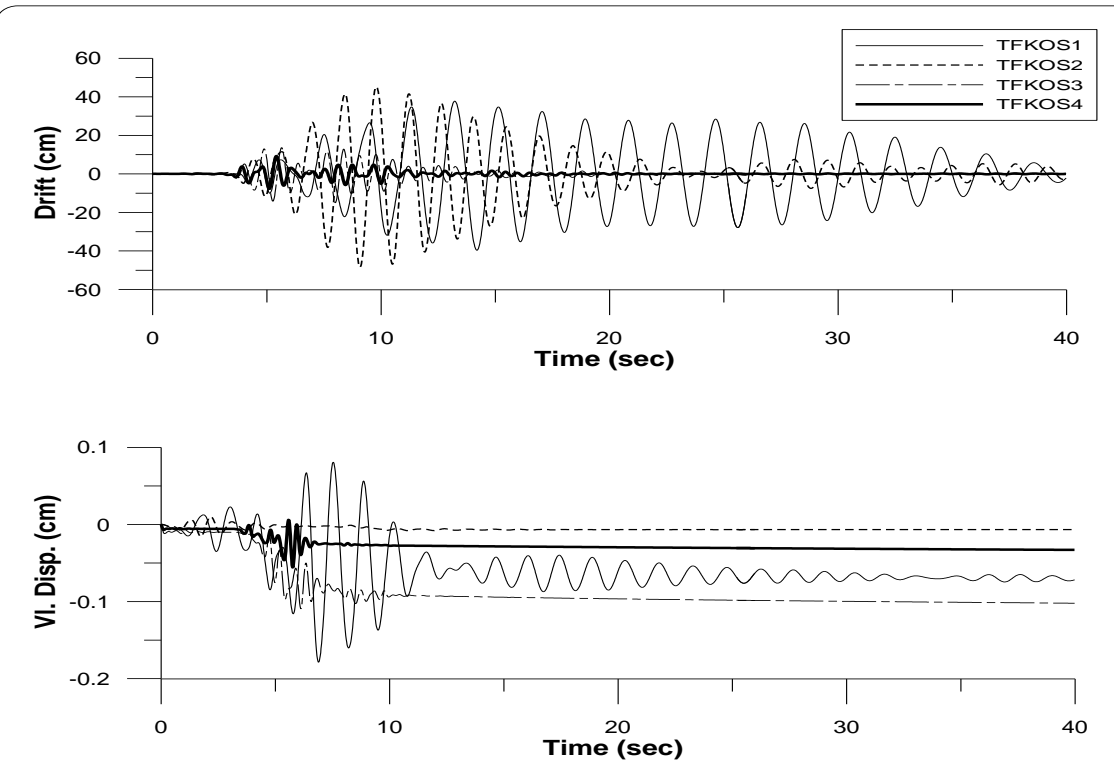

Fig.9 Drift time history and the vertical displacement for TFKOS1, TFKOS2, TFKOS3 and TFKOS4 

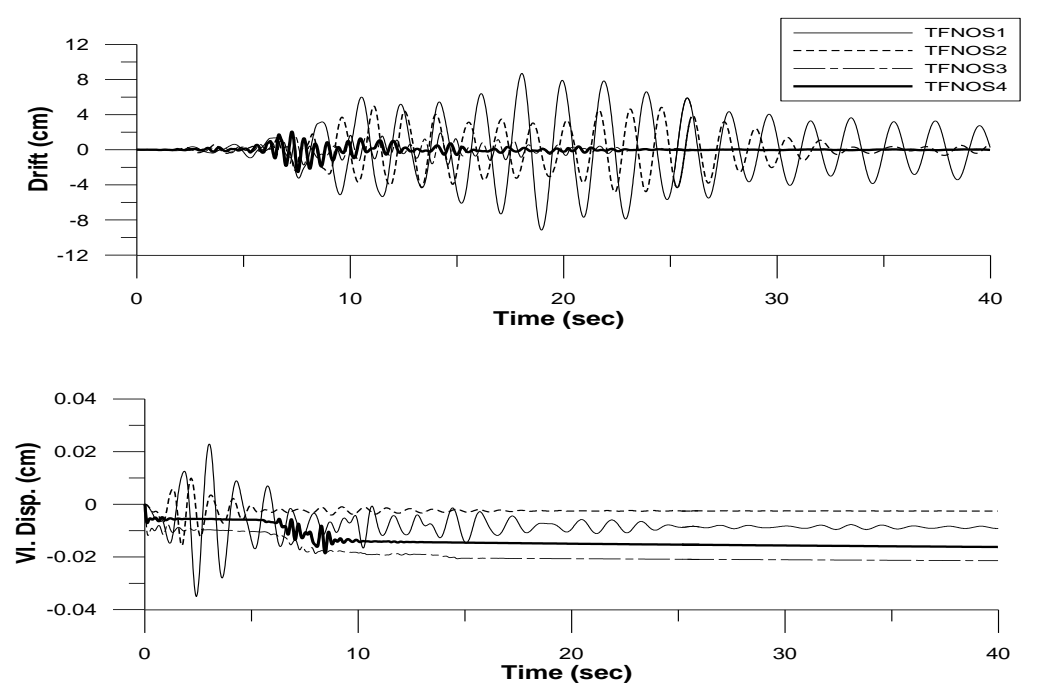

Fig.10 Drift time history and the vertical displacement for TENOS1, TENOS2, TENOS3 and TENOS4

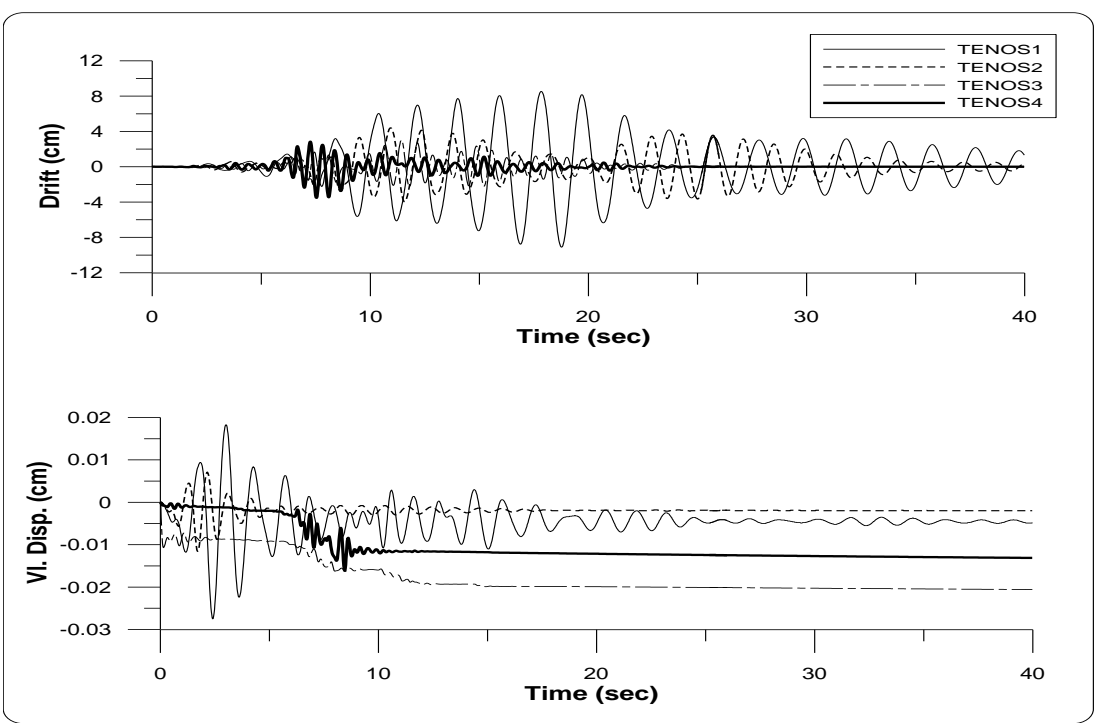

Fig.11 Drift time history and the vertical displacement for TFNOS1, TFNOS2, TFNOS3 and TFNOS4

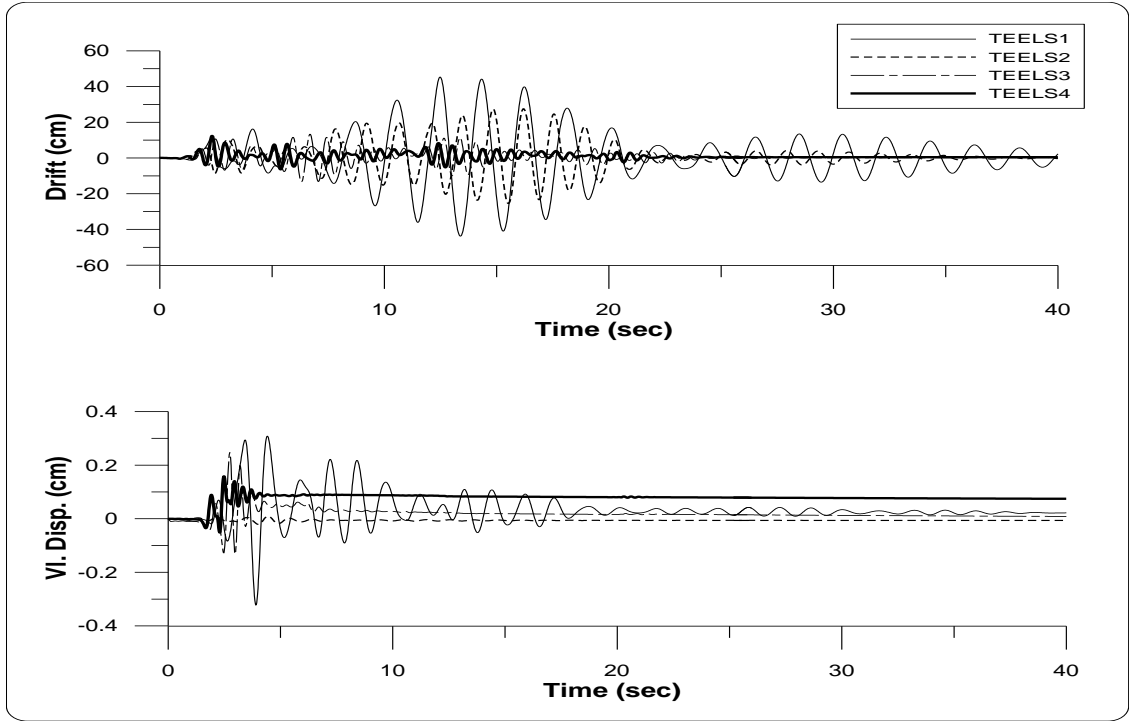

Fig.12 Drift time history and the vertical displacement for TEELS1, TEELS2, TEELS3 and TEELS4 


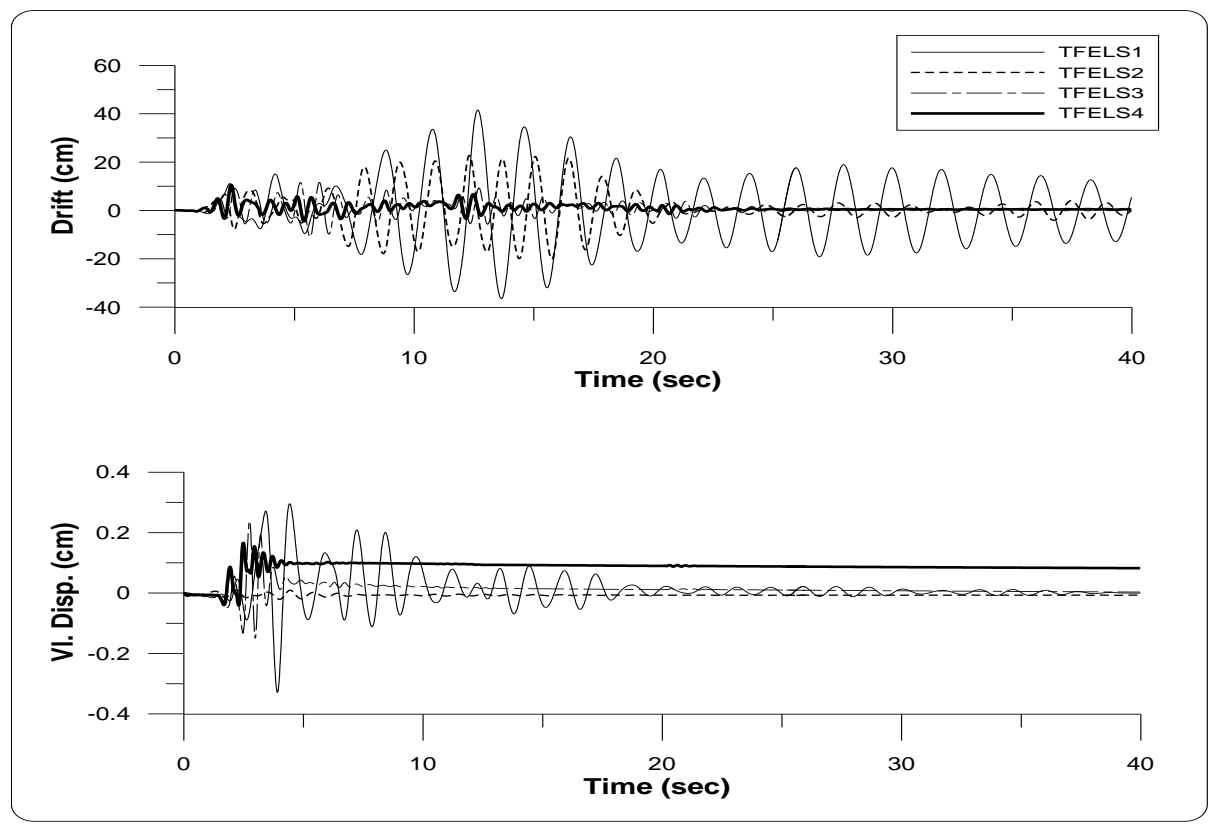

Fig.13 Drift time history and the vertical displacement for TFELS1, TFELS2, TFELS3 and TFELS4

The drift time history and the vertical displacement for TFELS1, TFELS2, TFELS3 and TFELS4 can be seen in Fig.13. The maximum drift for TFELS1 is $41.54 \mathrm{~cm}$ at time $12.66 \mathrm{sec}, 22.73 \mathrm{~cm}$ at time $12.32 \mathrm{sec}$ for TFELS2, $11.64 \mathrm{~cm}$ at time $6.04 \mathrm{sec}$ for TFELS3 and $10.52 \mathrm{~cm}$ at time 2.36 for TFELS4.

\section{Conclusion}

A. Numerical modeling of elevated water tanks resting on different soils considering different excitations are developed. The analysis of the results leads to many important conclusions.

B. A summary of the most general conclusions are as follows:

C. -Different types of soil strongly affects the response of the elevated water tanks; the rigid soils reduce the value of drift and the maximum value of drift occurs at a time near the time of PGA of the earthquake records.

D. - The drift and vertical displacements are completely independent (vertical displacements have been detected under the vertical symmetric axis of the structure) because of the random nature of the seismic action and the nonlinear behavior of the soil.

E. - The seismic response of the elevated water tanks strongly changed with different excitations in spite of the same PGA.

F. It is observed that the maximum drift values in case of full tanks are less than the maximum drift values of empty tanks

\section{REFERENCES}

[1] ADINA (2012). Automatic Dynamic Incrimental Nonlinear Analysis. ADINA R \& D, Inc. USA.

[2] ANSYS (2012). Swansom analysis system Inc. Houston. Pennsylvanis. USA.

[3] Boyce, W.H. (1995). Vibration tests on a simple water tower. Fifth World Conference on Earthquake Engineering Research. Vol 1, 220-225.

[4] Bowles, J.E. (1977). Foundation analysis and design, McGraw, Inc.

[5] Dutta, S.C., Dutta, S., Roy, R. (2009). Dynamic behavior of R/C elevated water tanks with soil-structure interaction. Journal of Engineering Structures. Vol 31, 2617-2629.

[6] Dutta, S., Mandal, A., Dutta, S.C. (2004). Soil-structure interaction in dynamic behavior of elevated tanks with alternate frame stagging configurations. Journal of Sound Vibration 277. Vol 1, 825-853.

[7] El Khawaga, A.M., El Nimr, A.E., Gabr, A.M.(2015). Seismic assessment of elevated water tanks, Proceeding the IZIIS-50 Conference. Paper no153.

[8] El sharkawy, M. (2008). Seismic analysis of seismically isolated water tanks, MSc thesis, Tanta University, Egypt.

[9] Haroun, M.A., Housner, G.W. (1981). Seismic design of liquid storage tanks. ASCE journal of Technical Councils 107. Vol 1, 191-207.

[10] Housner, G.W. (1963). Dynamic behavior of water tanks. Bulletin of seismological society of the america. Vol 53, 381-387.

[11]Hirde, S., Bajare, A. (2011). Seismic performance of elevated water tanks. International journal of advanced Engineering Research and studies. Vol I:I, 78-87.

[12] Jabar, A.M., Patel, H.S. (2012). Seismic behavior of elevated water tank under different stagging pattern and earthquake charactristics. International journal of advanced Engineering Research and studies. Vol I:III, 293-296.

[13] Livaoglu, R., Dogangun, A. (2006). Simplified seismic analysis procedures for elevated tanks considering fluid-structure-soil interaction. Journal of Fluids and Structures. Vol 22, 421-439.

[14] Moslemi, M., Kianoush, M.R., Pogorzelski, W. (2001). Seismic response of liquid-filled elevated water tanks. Journal of Engineering Structures. Vol 33, 2074-2084.

[15] Rai, D.C., Singh, B. (2004). Seismic design of concrete pedestal support tanks. 13th World Conference on Earthquake Engineering. Paper no 230.

[16]Sezen, H., Livaoglu, R., Dogangun, A. (2008). Dynamic analysis and seismic performance evaluation of above ground liquid containing tanks. Journal of Engineering Structures. Vol 30, 794-803. 
[17] Shrimali, M.K., Jangid, R.S. (2003). Earthquake response of isolated elevated liquid storage steel tanks. Journal of Constructural Steel Research. Vol 59, 1267-1288.

[18] Soroushnia, S., Tafreshi, S.T., Omidinasab, F., Beheshtian, N., Soroushnia, S. (2011) Seismic performance of RC elevated water tanks with frame staging and exhibition damage pattern. Proceeding the Twelfth East Asia-Pacific Conference on Structural Engineering and Construction. 3076-3087 